WIKTOR CZERNIANIN* - WROCŁAW

\title{
PRZECHOWYWANIE I KONSERWACJA ZBIORÓW W POLSKIM PRAWIE BIBLIOTECZNYM DO ROKU 1918
}

Przypomnijmy najpierw pewne oczywistości. Pierwszą, że przepisy prawne są podstawą każdej organizacji, dlatego działalność bibliotek byłaby również niemożliwa bez określonych uwarunkowań prawnych ${ }^{1}$. Drugą, że w badaniach organizacji i działalności bibliotek nie można pominąć bardzo ważnego aspektu praw$n^{n e g o}{ }^{2}$. I trzecią, że trzeba czynić prawo biblioteczne przedmiotem badań, zresztą pod kątem różnych zagadnień bibliotecznych ${ }^{3}$. Tym naszym będzie problematyka przechowywania i konserwacji zbiorów w wspomnianym prawodawstwie, czyli kształtowanie się jednej z podstawowych funkcji bibliotecznych, której celem jest zabezpieczenie zbiorów przed zniszczeniem - także prawne - oraz ich utrzymanie w gotowości do udostępniania. (Poprzestańmy na razie na tym bardzo ogólnym określeniu, gdyż rozwój kodyfikacji tego zagadnienia będzie obecny w dalszej części niniejszego artykułu). O wiele bardziej wypada bowiem na wstępie przedstawić pojęcie prawa bibliotecznego i usystematyzować ważność, kolejność oraz wzajemną zależność, a więc hierarchię poszczególnych aktów prawnych związanych ze sprawami bibliotecznymi. Według wybitnego znawcy przedmiotu Tadeusza Zarzębskiego: „Prawo biblioteczne stanowi ogół norm postępowania, dotyczących organizacji i funkcjonowania bibliotek, ustanawianych przez organy władzy i administracji państwowej. [...] Pojęcie ,,prawo biblioteczne” obejmuje zatem wszelkie akty normatywne - także tzw. akty interpretacyjne, jak: okólniki, instrukcje, wytyczne, urzędowe zalecenia w formie pism i listów okólnych itp. dokumenty o zasięgu ogólnokrajowym albo resortowym - które w całości lub w części aktu normatywnego odnoszą się wyłącznie do spraw bibliotecznych

${ }^{*}$ Wiktor Czernianin - dr literaturoznawstwa, kustosz dyplomowany, kierownik Biblioteki Instytutu Psychologii Uniwersytetu Wrocławskiego.

${ }^{1}$ M. Pidłypczak-Majerowicz, Polskie prawo biblioteczne po drugiej wojnie światowej, w: Biblioteki naukowe, ośrodki naukowej informacji wojskowej wyższych uczelni wojskowych. (Materiaty konferencji. Wrocław 02041998 r.), Wrocław 1998, s.167.

${ }^{2}$ T. Zarzębski, Polskie prawo biblioteczne 1773-1990, Warszawa 1991, s.14.

${ }^{3}$ Tamże. 
i z tego punktu widzenia zostały wydane. W ten sposób wyodrębnia się przedmiotowo przepisy normatywne odnoszące się do spraw bibliotecznych"4. Z kolei hierarchia norm prawnych - cytujemy dalej Zarzębskiego - ,[...] zawartych w konkretnym akcie prawnym, wyrażona jest również w samej nazwie aktu (ustawa - dekret -rozporządzenie - uchwała rządu - zarządzenie - decyzja - rozkaz - wytyczne - instrukcja - pismo urzędu centralnego - list KEN), a w jego tytule (lub w przepisach wstępnych) określony jest także dopuszczalny zasięg i zakres stosowania tego prawa. Cały system prawny budowany jest na podstawie przepisów ustawy zasadniczej (konstytucja państwa) oraz przepisów ustaw (dekretów) w sprawach szczegółowych"s. W przypadku polskiego prawa bibliotecznego, dla każdego z dwóch omawianych tu okresów historycznych, będą to: w wolnej Rzeczpospolitej do rozbiorów - konstytucja Sejmu z dnia 14 X 1773 roku powołująca Komisję Edukacji Narodowej i określająca jej uprawnienia, także w sprawach bibliotecznych; w Polsce porozbiorowej - odpowiedniej rangi akty prawne odnoszące się do organizacji i funkcjonowania bibliotek, wydane w poszczególnych zaborach, bądź w przejściowych tworach historyczno-politycznych polskiej państwowości, czyli zwłaszcza w Księstwie Warszawskim i Królestwie Polskim. Na przykład ukaz cesarski z 24 I 1803 roku pod nazwą Zasady powszechnego oświecenia opracowany w znacznej mierze przez Polaków, czy też akty prawne Dyrekcji Edukacji Narodowej powołanej w 1810 roku w ramach Ministerstwa Spraw Wewnętrznych Księstwa Warszawskiego (1807-1815). W szczególności Wewnętrzne urzadzenie szkót departamentowych przyjęte na Sessyi Dyrekcyi Edukacyiney dnia 16 listopada 1812 r. albo akty prawne Komissyi Rzadowej Wyznań Religijnych i Oświecenia Publicznego Królestwa Polskiego (1815-1830), a później Ustawa o wychowaniu publicznem w Królestwie Polskim z 1862 roku.

Motywując przyjętą tutaj chronologię historyczną warto przypomnieć wyraźnie określoną - bo wzrastającą - rolę książki w omawianych epokach, a co za tym idzie również bibliotek. W czasach oświecenia bowiem, jak piszą badacze, wzrosło niebywale zainteresowanie książką jako środkiem przekazu informacji, źródłem wiedzy i dokumentem kultury narodowej ${ }^{6}$. W tym właśnie czasie zrodziła się idea biblioteki narodowej. Zwrócono też uwagę na oświatowy cel działalności bibliotek i większość z nich otworzono dla szerokiego kręgu czytelników. Natomiast w okresie rozbiorowym rola piśmiennictwa i książki była przede wszystkim w zachowaniu tożsamości narodowej ${ }^{7}$. Celem bibliotek było zwłaszcza uchronienie tych pamiątek kultury polskiej przed zniszczeniem, a dopiero potem służba nauce. Boleśnie pamiętano - i to przez całe dziesięciolecia - co stało się z Biblioteką Załuskich po tragicznej bitwie maciejowickiej i rzezi Pragi (1794). Suworow zarządził wtedy, na mocy specjalnego reskryptu Katarzyny II (z 21 XI 1794) wywiezienie Biblioteki do Petersburga ${ }^{8}$. Nie można tu nie zacytować (za

${ }^{4}$ Tamże, s.10.

${ }^{5}$ Tamże, s.12-13.

${ }^{6}$ Zob. np. A. Żbikowska-Migoń, Książka naukowa w kulturze polskiego oświecenia, Warszawa 1977.

${ }^{7}$ K. Maleczyńska, Książki i biblioteki w Polsce okresu zaborów, Wrocław 1987, s. 5.

${ }^{8}$ Zarzębski, Polskie prawo, s.22. 
T. Zarzębskim) jakże jeszcze emocjonalnego opisu tego wydarzenia z 1833 roku autorstwa Adama Mickiewicza: „Później, zawładnąwszy Warszawą, rozkazała zabrać i przewieźć na swój dwór do Petersburga wielką bibliotekę narodową, utworzoną przez biskupa J. A. Załuskiego i darowaną Rzeczpospolitej. Kozacy, którym polecono zapakowanie, rąbali i piłowali tomy, których format wydawał im się za duży lub niewygodny. Tysiące kibitek pod eskortą pułku Kozaków, tworzyło orszak pogrzebowy całe literatury, skazanej na pochowanie żywcem w ziemi odległego i wrogiego kraju. Po drodze sprzedawano wiele tych wozów Żydom i chłopom rosyjskim. (Po otwarciu Cesarskiej Biblioteki Publicznej w Petersburgu) zabroniono cudzoziemcom, a zwłaszcza Polakom korzystać z tych książek, a nawet zbliżać się do nich" ". Zatem już chociażby z powyższych powodów, funkcja przechowywania i konserwacji zbiorów w tychże okresach, niejako „musiała” stać się naczelnym zadaniem polskich bibliotek i wyraźnie zaznaczyć w polskim prawodawstwie i piśmiennictwie bibliotecznym.

W opracowaniach odnoszących się do polskiego prawa bibliotecznego zwykło przyjmować się rok 1773 jako początek działań państwa w zakresie regulacji spraw bibliotecznych ${ }^{10}$. Od tego początku, silny wpływ na kształtowanie się właśnie spraw bibliotecznych związanych z przechowywaniem zbiorów wywarły akty prawne Komisji Edukacji Narodowej. Zwłaszcza te dotyczące bibliotek wyższych, szkolnych i publicznych, które były przedmiotem ciągłej troski i działań Komisji ${ }^{11}$. Jednakże KEN, co trzeba wyraźnie podkreślić, nie zaczynała formułować prawodawstwa bibliotecznego w jakiejś próżni intelektualno-prawnej. Korzystała raczej $\mathrm{z}$ istniejących już wzorów przepisów bibliotekarstwa zakonnego, m.in. jezuitów, bazylianów, pijarów i reformatorów ${ }^{12}$. Przyjrzyjmy się zatem jaką rolę $\mathrm{w}$ przepisach tegoż bibliotekarstwa odgrywała funkcja przechowywania i konserwacji zbiorów. Wedle reguł zakonnych jezuitów - jak pisze Ludwik Grzebień - „bezpośrednimi przełożonymi nad księgozbiorami byli prefekci bibliotek. Mianował ich przełożony prowincji zakonnej"13. Istniały więc prawne zabezpieczenia zbiorów. Również faktyczne, gdyż prefekt ów zachowywał pieczę nad ich pomieszczeniem, tzn.: ,[...] miał odpowiednio zamykać magazyn biblioteczny i strzec kluczy, użyczając ich jedynie tym, którzy posiadają specjalne zezwolenie od kompetentnych przełożonych" ${ }^{\prime 4}$. Wykonywał także prace związane z ustawieniem księgozbioru: „[...] książki układał w bibliotece w porządku przedmiotowym, aby zaś ułatwić poszukiwanie potrzebnej pozycji, miał starać się o wypisanie autora i tytułu na

${ }^{9}$ Grabież polskich bibliotek. Dzieła, t. 6. 1950, s. 177-180 (cytuję za Zarzębski, Polskie prawo, s. 22, przypis 10 ).

${ }^{10}$ M. Łodyński, U kolebki polskiej polityki bibliotecznej (1774-1794,. Warszawa 1935; Zarzębski, Polskie prawo, s. 7; M. Pidłypczak-Majerowicz..., s.167.

${ }^{11}$ Zarzębski, Polskie prawo, s. 23.

${ }_{12}$ M. Pidłypczak-Majerowicz, Biblioteki i bibliotekarstwo zakonne na wschodnich ziemiach Rzeczpospolitej w XVII-XVIII wieku, Wrocław 1996, s. 32.

${ }^{13}$ L. Grzebień, Organizacja bibliotek jezuickich w Polsce od XVI do XVIII wieku, „Archiwa, Biblioteki i Muzea Kościelne”, 30 (1975) s. 243.

${ }^{14}$ Tamże. 
grzbiecie każdego tomu" "15. Zaś co do gotowości do udostępniania i kontroli zbiorów wykonywat: ,[...] odpowiednie katalogi, które przedstawiał przełożonemu prowincji podczas wizytacji kolegium" ${ }^{16}$. Z tej praktyki zakonnej jezuitów wyłaniają się pierwsze problemy związane z przechowywaniem zbiorów dotyczące: zabezpieczenia prawnego zbiorów przez ustanowienie personalnych kurateli, pomieszczeń dla nich, ich ustawienia oraz obsługi udostępniania i kontroli. Z kolei przepis o bibliotekach bazylianów, wzorowany w pewnym stopniu na przepisach jezuitów, zakładał, że: „każda biblioteka klasztorna miała służyć jako szczególna pomoc dla światłych i uczonych zakonników. Aby osiągnąć ten cel, przepis przewidywał m.in. specjalne nakłady finansowe oraz starannie dobraną obsługę biblioteczną" "17. Jakież to bliskie założeniom działalności późniejszej Komisji Edukacji Narodowej. U bazylianów, znów podobnie jak u jezuitów, prawnie: „bezpośrednią pieczę nad księgozbiorem klasztornym sprawował bibliotekarzzakonnik" ${ }^{18}$. Zakonne przepisy biblioteczne zobowiązywały go także: ,[...] do porządkowania pomieszczenia bibliotecznego. Bibliotekarz, aby uchronić księgozbiór przed wilgocią i robactwem, zamiatał podłogę, wycierał kurze i wietrzył salę biblioteczną"19. Książki na półkach ustawiano według podziału katalogowego. Sygnatura lokalna składała się z cyfrowego lub literowego oznaczenia działu wiedzy, numeru szafy i kolejnego numeru na półce. Ponadto w zakresie obsługi udostępniania i kontroli: ,,...] bibliotekarz miał pilnować ksiąg wypożyczonych na miejscu bądź - w wyjątkowych wypadkach - za zgodą superiora [tj. przełożonego klasztoru] poza obręb biblioteki. Tak wielka piecza nad udostępnianiem ksiąg była podyktowana wysokimi ocenami książek, które stanowiły część majątku klasztornego. [...] Zalecenia reguły zakonnej nie były jednak należycie przestrzegane. [...] Przechowywanie i porządkowanie księgozbioru klasztornego było określane przepisami. Do obowiązków bibliotekarza należało dopilnowanie, aby księgi miały dokładny katalog z wyraźnie oznaczonym miejscem na półce [czyli sygnatury], ułatwiającym szybkie znalezienie dzieła"20. Bazylianie gromadząc księgi zwracali uwagę na ich oprawę introligatorską. Do oprawiania swoich ksiąg zatrudniali bazyliańskich klasztornych mistrzów sztuki introligatorskiej lub rzemieślników spoza społeczności zakonnej ${ }^{21}$. W ten sposób postępowały także inne zakony. Zatem do szeroko rozumianej kodyfikacji problematyki przechowywania zbiorów, tj. ich zabezpieczania (także prawnego), przechowywania w pomieszczeniach, ustawienia, obsługi udostępniania i kontroli, dochodzi wreszcie zagadnienie konserwacji (jako realizowana metoda postępowania mająca na celu zapewnienie długotrwałości przechowywanych książek).

${ }^{15}$ Tamże.

${ }^{16}$ Tamże.

${ }^{17}$ M.Pidłypczak-Majerowicz, Bazylianie w Koronie i na Litwie. Szkoły, książki w działalności zakonu. Wrocław 1986, s.144.

${ }^{18}$ Tamże, s.146.

${ }^{19}$ Tamże, s.151.

${ }^{20}$ Tamże, s. 145-150.

${ }^{21}$ Tamże, s. 152. 
W konkluzji trzeba zauważyć, że choć starania bazylianów w sprawie zabezpieczenia księgozbiorów nie były jednolite, to jednak biblioteki klasztorne przechowały w dobrym stanie dużą ilość ksiąg ${ }^{22}$. Ten stan rzeczy był nie bez znaczenia dla tworzących się później bibliotek na ziemiach polskich, gdyż zasilały je także zbiory klasztorne, usilnie poszukiwane przez organizatorów, np. Samuela Lindego ${ }^{23}$. Trzeba jeszcze dodać, że przepisy zakonne dyscyplinowały również użytkowników bibliotek zakonnych, nakazując właściwe obchodzenie się z wypożyczonymi dziełami i terminowe zwroty wypożyczonych ksiąg ${ }^{24}$. Te wstępne ustalenia pozwolą nam nieco inaczej spojrzeć na działalność prawną KEN związaną $\mathrm{z}$ organizacją i funkcjonowaniem bibliotek.

Oto przepis KEN dla rektorów szkół z 1774 roku:,,[...] 11. Biblioteki przy szkołach do dozoru rektorów należą. Przybierze sobie do biblioteki rektor jednego z nauczycielów. Ochędóstwa obydwa doglądać będą książki nikomu bez zapisania nie dawać, od każdego zaś z pilnością odbierać. Katalogi bibliotek komunikowane będą Komisji. [TZ 1991, s.69]"'25. Czyż nie jest to przepis zabezpieczający zbiory oraz nakazujący utrzymanie ich w należytym porządku i w gotowości do udostępniania? Oczywiście, takie określenie nie padło, lecz zawiera je bez wątpienia intencja tego postanowienia wyrażona po staropolsku, m.in. w słowie „ochędóstwo". Cóż ono znaczy lub raczej, cóż ono znaczyło dla ówczesnego czytelnika znającego ten język? Otóż ni mniej, ni więcej tylko „czystość, schludność, porządek"26. Wyjaśnienie zakresu pojęciowego tego wyrazu jest ważne, gdyż występuje on również jako kluczowy w innych ustawach KEN, silnie określając konieczność utrzymania porządku w bibliotece. Na przykład w Ustawie KEN dla stanu akademickiego i na szkoły $w$ krajach Rzeczypospolitej przepisane 2 lutego $1790 \mathrm{r}$. Tam m.in. o urzędzie bibliotekarza: ,[...] obowiązkiem jego będzie: 1-mo. Porządku, ochędóstwa i całości dostrzegać nie tylko biblioteki publicznej, ale też ksiąg wszelakich $\mathrm{w}$ gabinetach i stancjach profesorów złożonych, a onym nieodbicie potrzebnych, rejestra porządnie utrzymywać, przybyte kosztem Komisji, bądź darem od kogo, księgi wpisywać podług roz.1. art.10" (TZ 1991, s.74). Urok tej staropolszczyzny przebija, jak widać, nawet poprzez sformułowania zwięzłe i jednoznaczne. Jednoznaczne, bowiem przepisy te bardzo jasno zabezpieczają przechowywane zbiory, w tym przypadku - przez prawne zobowiązanie bibliotekarza do dbałości o nie. Przepisy te odegrały ważną rolę w tej sprawie, gdyż jak zauważył Marian Łodyński: ,[...] mimo trudnych warunków, w jakich Komisja Edukacyjna zastała biblioteki i mimo braku odpowiednio przygotowanych pracowników, a głównie słabej władzy wykonawczej - poczynania Komisji Edukacyjnej wydały szereg dodatnich rezultatów. Przede wszystkim ciągłe podkreślanie potrzeby porządku i znaczenia bibliotek podniosło szersze odczucie zna-

${ }^{22}$ Tamże, s. 153.

${ }^{23}$ Zob. np. Ewa Słodkowska, Biblioteki w Królestwie Polskim 1815-1830. Warszawa 1996.

${ }^{24}$ M.Pidłypczak-Majerowicz, Bibliotekarstwo zakonne..., s.52.

${ }^{25}$ Skrót „TZ 1991” oznacza cytowaną powyżej książkę T .Zarzębskiego, wydanie z 1991 roku, po skrócie podaję stronę.

${ }^{26}$ Zob. Stownik języka polskiego. red. W. Doroszewski. Warszawa 1963. Tom V: Nie O. Hasło: ochędóstwo, 1.. przestrz. „czystość, schludność, porządek” itp.. s.603. 
czenia księgozbiorów, a z tym zwiększyło w szeregu środowisk zapobiegliwość o nie i doprowadziło $\mathrm{w}$ wielu szkołach do uporządkowania znajdujących się tam zbiorów"27. Innym przejawem troski o należyte przechowywanie zbiorów były odpowiednie pomieszczenia biblioteczne, w tym także dla czytelników. Według Planu instrukcji i edukacji przepisanego od Komisji dla szkót Głównych i innych w krajach Rzeczypospolitej (po 1794): [..] nie tylko jest potrzebne opatrzenie bibliotek wyborem książek, [...], ale nadto obmyślenie miejsca wygodnego nawet w zimie do czytania i wypisywania" (TZ 1991, s. 76). Otóż dowiadujemy się z raportów wizytatorów Komisji, a przedstawionych przez Mariana Łodyńskiego, że KEN: ,[...] przede wszystkim uwagę swą skierowała na pomieszczenia [wszystkie podkreślenia w cytowanych tekstach pochodzą ode mnie] biblioteczne, które znajdowały się niejednokrotnie w stanie rozpaczliwym i to bez względu na wielkość księgozbioru"28. Pośrednio o utrzymywaniu budynków biblioteki mówi cytowana już ustawa KEN dla stanu akademickiego z 1790 roku w rozdziale IX. Dom: „l-mo. Pod imieniem domu rozumie się mieszkanie zgromadzenia, kościół, szkoły, biblioteki,muzeum. [...]. 20-o. Opatrzenie bibliotek, muzeów i inne nadzwyczajne potrzeby do osobnych Komisji wydatków należeć będą" (TZ 1991, s.75).

Innym zagadnieniem podstawowego znaczenia dla przechowywania zbiorów było ich ustawienie i konserwacja. Te sprawy biblioteczne regulowały już wcześniej cytowane przepisy ogólne o konieczności doprowadzania do porządku nagromadzonych zbiorów; w tym katalogowania, czyli domyślnie do odpowiedniego ładu wewnętrznego księgozbiorów, nieodzownego dla ich udostępniania czytelnikom. Prace porządkowe, poprzedzone opracowaniami katalogowymi - o czym pisze nieoceniony Łodyński - dotyczyły odpowiedniego ustawienia zbiorów ${ }^{29}$. Katalogowanie właśnie: ,[...] miało tym większe znaczenie, że na ogół przyjęty system katalogu klasowego miał odpowiadać ustawieniu zbiorów w magazynie" ${ }^{\prime 30}$. Niech nas zatem nie dziwi wielki nacisk na opracowanie katalogowe zbiorów obecne w aktach prawnych KEN, gdyż w ówczesnej literaturze bibliotecznej zagranicznej ${ }^{31}$, panowało: ,[...] rewolucyjne, uderzające nowoczesnością hasło, że kluczem do biblioteki jest katalog, a nie jej ustawienie"32.

Reasumując ten fragment analiz, trzeba podkreślić, że niewątpliwie wielki jest dorobek Komisji Edukacji Narodowej w kształtowaniu i utrwalaniu prawa bibliotecznego chroniącego księgozbiory w bibliotekach, jak i oczywiście roli samych bibliotek jako instytucji o pierwszorzędnym znaczeniu w szerzeniu oświaty i nauki. W interesującym nas tu zakresie, zapisy prawne KEN, choć zawierające takie ogólne określenia jak „,porządek”, czy „,ochędóstwo”, to jednak były przecież podstawą niezmiernie ważnych decyzji, a zwłaszcza działań w sprawie szeroko rozumianego przechowywania i konserwacji zbiorów. $Z$ naczelną zasadą prawidłowej organizacji i funkcjonowania bibliotek. Konstatacja ta jest tym smutniejsza,

\footnotetext{
${ }^{27}$ M. Łodyński..., s. 19.

${ }^{28}$ Tamże, s. 30.

${ }^{29}$ Tamże, s. 31.

${ }^{30}$ Tamże.

${ }^{31}$ Tamże.

${ }^{32}$ Tamże, s.76. przypis 162.
} 
że praktycznie, jeżeli to sobie uświadomimy, dorobek bibliotekarstwa tamtego okresu został przecież doszczętnie zniszczony ${ }^{33}$. Jednakże jego prawodawstwo biblioteczne, m.in. tyczące przechowywania zbiorów, promieniowało jeszcze na następne dziesięciolecia. Zwłaszcza na akty prawne Dyrekcji Edukacji Narodowej powołanej w 1810 roku w ramach Ministerstwa Spraw Wewnętrznych Księstwa Warszawskiego, a działającej pod niewątpliwym wpływem $\mathrm{KEN}^{34}$. W aktach tych, które były faktycznie statutami i regulaminami szkół, sformułowano również przepisy odnoszące się do organizacji oraz funkcjonowania bibliotek. (TZ 1997, s.24) ${ }^{35}$. Oczywiście, także do przechowywania zbiorów. Wynika z nich, np. $\mathrm{z}$ Wewnętrznego urządzenia szkót departamentowych [tj. przygotowujących do studiów wyższych] przyjętego na Sessyi Dyrekcyi Edukacyiney dnia 16 listopada 1812 r., że staranie o bibliotekę powierzano nadrzędnie zwykle rektorom i jednemu z nauczycieli: ,„[...]. Roz. 54. Rektor stara się o pomnożenie zbiorów biblioteki [...] i czuwa nad całością tychże, bezpośredni zaś dozór poleca iednemu z nauczycielów" (TZ 1997, s. 99). Szczegółowo zaś wedle tychże samych przepisów, ale w dziale V, w roz.90, czytamy: „Bibliotekaryusza iest obowiązkiem książki w bibliotece i iey szafach pod takiemi znakami lub napisami, w takim porządku zawsze utrzymywać, iaki za wiadomością Rektora wprowadzonym będzie" (TZ 1997, s. 101). Ten raczej niewielki zapis posłużyć może za przykład regulacji prawnej bibliotekarskich działań związanych z przechowywaniem zbiorów. Według niego, to bibliotekaryusz (swoja drogą, cóż to za pyszna nazwa zawodu!) bezpośrednio ma obowiązek zadbania o należyte przechowywanie zbiorów. A więc zabezpieczenia księgozbioru „w bibliotece i iey szafach”, dalej: utrzymania go „pod takiemi znakami i napisami”, aby był w gotowości do udostępniania, nadto obowiązek określonego ustawienia, mianowicie ,W takim porządku [...] iaki za wiadomością Rektora wprowadzony będzie". Czyż trzeba dodawać, że działania takie razem wzięte, znakomicie chroniły książki? Zatem jako profilaktyczna metoda postępowania przedłużała żywot obiektom bibliotecznym, a więc służyła ich szeroko pojętej konserwacji. To jednak bardziej wynika z intencji i logiki przepisu, niż z jego litery. Zaznaczyć warto, że inne regulacje prawne zawarte dla różnych rodzajów szkół w Księstwie Warszawskim, są prawie identyczne - nie tylko w interesującym nas zagadnieniu. Wypada tutaj podkreślić, że jak pisze Zarzębski: ,[...] już w opinii współczesnych - uznane były za wzorowe, skoro powtórzono je (w nieznacznie zmienionym brzmieniu) - w aktach prawnych (dla szkół wojewódzkich i wydziałowych), zatwierdzonych w 1819 roku, a więc już w Królestwie Polskim" (TZ 1997, s. 25).

Przyjmując porozbiorowy układ polityczny, omówić teraz należy prawodawstwo biblioteczne Rzeczpospolitej Krakowskiej istniejącej w latach 1815-1846, oczywiście w interesującym nas wąskim zakresie. Naczelnym aktem prawnym był tu Statut urzadzajacy Uniwersytet Krakowski z 16 października 1818 r., w którym znajdujemy także przepisy prawa bibliotecznego. Zarzębski zauważył, że:

${ }^{33}$ T. Zarzębski, Geneza, życie i nauki dekretu. „Przegląd Biblioteczny” 1986. nr 3/4, s.280.

${ }^{34}$ T. Zarzębski, Prawo biblioteczne w okresie zaborów 1795-1918. 1939-1945. Warszawa 1997, s. 23.

${ }^{35}$ Skrót ten oznacza wyżej cytowane dzieło T. Zarzębskiego z 1997 roku. potem podaję stronę. 
„Otwarcie Biblioteki dla publiczności było jak najwyraźniejszym nawiązaniem do postanowień Komisji Edukacji Narodowej. Natomiast przepisy porządkowe odnoszące się do funkcjonowania biblioteki oraz organizowania obiegowego udostępniania czasopism, niezaprzeczenie przypominają wzorcowe przepisy dla szkół departamentowych, ustanowione w 1812 roku w Księstwie Warszawskim" (TZ 1997, s.28). Dotyczy to także spraw bibliotecznych związanych z przechowywaniem i konserwacją zbiorów. Oto rozdz. 169 wspominanego Statutu: „Bibliotekaryusza obowiązkiem iest. Książki w Bibliotece, pod takiemi znakami lub napisami, i w takim porządku zawsze utrzymywać, iaki za wiadomością Rektora, iuż iest i będzie wprowadzonym" (TZ 1997, s. 109). Wśród sprawozdań składanych przez Senat wobec mieszkańców, znajdują się informacje dowodzące troski także o lokal Biblioteki. Dz. Rozp. Rzadowego Wolnego Niepodległego i ściśle Neutralnego M. Krakowa z r. 1828, Nr Dz. 5415, Senatu, s.20-21: „Biblioteka (Uniwersytecka) z funduszu na ten cel odkażanego stosowną liczbą dzieł pomnożoną została. (...) Z tem wszystkim lokal na Bibliotekę przeznaczony jest wielce niedogodny, a nawet zagrażający upadkiem prędkiego ratunku potrzebnie" (TZ 1997, s. 112). Sprawie zaradzono wreszcie w 1844 roku o czym pisze dokument na stronach 16-18: „Biblioteka (Uniwersytecka) z powodu przelania funduszu swojego w znacznej części do funduszów na kosztowne odbudowanie jej gmachów potrzebnych, nie mogła w upłynionym okresie znakomitych robić nabytków w zakupowaniu książek (...). Sama budowla, gdy ukończoną zostanie, będzie niewątpliwie najpiękniejszem i najtrwalszem dziełem jakie ta kraina w teraźniejszym czasie wyda i późnym wiekom w spuściźnie przekaże" (TZ 1997, s. 114). Fakt ten, dla jego dużej dla nas wagi, wart jest odnotowania. Zwłaszcza wobec szczupłości wydanych w Rzeczpospolitej Krakowskiej przepisów porządkowych i organizacyjnych odnoszących się do przechowywania zbiorów. Jeszcze jeden bardzo ważny przepis Statutu organicznego Uniwersytetu Krakowskiego z 1833 roku, bo prawnie zabezpieczający bibliotekę przez ustanowienie osoby odpowiedzialnej: Biblioteka jest pod dozorem Bibliotekarza, któremu adjunkt do pomocy i dwaj służący biblioteczni, do usług będą dodani” (TZ 1997, s.133).

W zaborze rosyjskim na zagrabionych terytoriach Polski panował w latach 1794 do 1801 niemal całkowity intelektualny zastój. Przełom nastąpił dopiero po powołaniu pierwszego w Rosji Ministerstwa Oświaty w 1802 roku, zresztą na wzór polskiej Komisji Edukacji Narodowej. Ukaz cesarski z 24. stycznia 1803 roku pod nazwą Zasady powszechnego oświecenia pozwolił też na organizowanie szkolnictwa. W akcie prawnym z dnia 18. maja 1803 roku odnoszącym się do Uniwersytetu Wileńskiego znajdujemy zapis dotyczący biblioteki: Wszystkie wyższe szkoły ( $\mathrm{tj}$. uniwersytety i gimnazja) będą miały swoje Biblioteki (...) na utrzymanie czego będą naznaczone w etatach summy" (TZ 1997, s. 31 i 116).

Również późniejsze utworzenie Królestwa Polskiego otworzyło nowy etap prawa bibliotecznego stanowionego na jego terytorium. Wprawdzie powstała 31 I 1818 roku Biblioteka Publiczna przy Uniwersytecie Warszawskim jako Biblioteka Królewskiego Uniwersytetu Warszawskiego, ale najciekawiej przedstawiają się akty prawne dotyczące Gimnazjum Wołyńskiego. Zwłaszcza Przepisy o Bibliotece Gimnazjum Wotyńskiego z 1818 roku, podpisane przez Kuratora 
Imperatorskiego Wileńskiego Uniwersytetu i Szkół jego Wydziału - księcia Adama Czartoryskiego. W przepisach tych szczególnie Powinności Bibliotekarza i Pomocników (TZ 1997, s. 126), bardzo ściśle przybliżają nam w niektórych punktach aspekt prawny przechowywania i konserwacji zbiorów. I tak w zakresie zabezpieczania zbiorów powinności bibliotekarza określał paragraf 21: „Bibliotekarz zarządza Biblioteką w tem wszystkim, co się do niej ściąga i sprawuje zwierzchni nad nią nadzór". Z kolei o należytym ustawieniu księgozbioru i gotowości do udostępniania mówił paragraf 22: ,Zaprowadzenie i utrzymanie porządku w Bibliotece jest pierwszym jego obowiązkiem. I dlatego dołoży starania, aby zbiór, dozorowi jego powierzony, odpowiadał w całej zupełności celom, iakie się zamierzają w tego rodzaju zakładach". Rzecz znamienna, jak wiele miejsca te przepisy poświęcają profilaktyce konserwacyjnej zbiorów i trosce o zachowanie jego wewnętrznego ładu, czyli ustawienia, porządku: „23. Przestrzegać będzie całości książek, dając baczenie, ażeby nic z Biblioteki straconem lub uszkodzonem nie zostało. [...]. 25. Corocznie po ukończeniu biegu nauk w Gimnazjum, zrobi rewizję książek już dla przywrócenia porządku, jeżeli ten naruszony został, już dla obaczenia, azali Biblioteka nie poniosła w czem szkody i uszczerbku". Wreszcie ważny element profilaktyki w przechowywaniu zbiorów wyrażony w przepisie zabezpieczającym przed zniszczeniem książki lub jej uszkodzeniem przez czytelnika z „Urządzenia Kommissyi $R$ [ządowej] W.R. i O.P. względem pożyczania xiag z Biblioteki Publicznej przy Królewsko-Warszawskim Uniwersytecie. Dan w Warszawie dnia 20 mca stycznia 1819: „9. Kto książkę Biblioteczną splami, zepsuie lub zgubi, zapłacić musi, kto część dzieła zepsute lub straci, cale dzieło zapłaci, a uszkodzone sobie zatrzyma" (TZ 1997, s. 127). O tym, że książki oprawiano świadczy pośrednio punkt 3 tegoż Urzadzenia.... „2. Professor pofrzebuiący dzieła udaje się do Biblioteki. 3. Tam złoży na odebrane dzieła kwit, z należytem oznaczeniem tytułu, wyrażeniem roku i mieysca edycyi, formatu i oprawy; podpisem swoim, wyrażając swoje mieszkanie”. Przepis chroniący zbiory przed ewentualnym ich uszkodzeniem ze strony czytelnika, dosłownie powtarza się jeszcze w Wewnętrznych urządzeniach skół woiewódzkich i Wewnętrznych urządzeniach Szkót Wydziałowych - obydwa z 1820 roku (TZ 1997, s.129, 131). Że przepisy dotyczące udostępniania zbiorów były egzekwowane, niech świadczy fragment listu Józefa Jeżowskiego do Jana Czeczota z 17. listopada 1821 roku, pisany w Wilnie i tyczący się Biblioteki Uniwersytetu Wileńskiego: ,[...] Niech Franciszek [Malewski, przyjaciel A.Mickiewicza] napisze, gdzie podział «Monitora» francuskiego in folio, o który upomina się Biblioteka Uniwersytetu [Wileńskiego]”.

Tak wielką wagę, jaką przepisy biblioteczne tego okresu dają przechowywaniu i konserwacji zbiorów jest, jak się wydaje, uzasadniona teoretyczną podbudową ${ }^{36}$. Daje ją najpierwszy autorytet bibliotekarstwa polskiego (i zresztą nie tylko tej dyscypliny naukowej), mianowicie Joachim Lelewel. W Bibliograficznych ksiag dwoje pisze jakże ważne słowa: „Całe bibliotekarstwo, czyli przepisy, prawidła

${ }^{36}$ Zob. List Józefa Jeżowskiego do Jana Czeczota z dnia 17/19 listopada 1821 r. Wilno, w: Archiwum Filomatów, cz. 1, t. 4, 1821-1823, wyd. J. Czubek, Kraków 1913, s. 55. 
działań i urządzeń bibliotecznych na sześć podzielamy części. 1 Zabezpieczenie bibliotek i książek. 2. Uporządkowanie tworzącej się lub w nieładzie będącej biblioteki. 3. Utrzymanie zaprowadzonego porządku. 4. Użytek z bibliotek. 5. Pomnażanie zbiorów, środki ciągłego wzrostu. 6. Urządzenia, żeby biblioteczne działania dopełnione być mogły" ${ }^{37}$. Jak łatwo zauważyć, trzy pierwsze zagadnienia odnoszą się do szeroko rozumianego przechowywania i konserwacji zbiorów. I nie jest to, zwłaszcza u Lelewela, kolejność przypadkowa! Zabezpieczyć zbiory, uporządkować, utrzymać w tym porządku - dla współczesnych i potomnych, to było główne zadanie ówczesnych twórców kultury i nauki polskiej, świetnie oddające polityczno-społeczny nastrój tamtej epoki. Lelewel omawiając powyższe poszczególne problemy przechowywania i konserwacji zbiorów, właściwie je ustalił, a to poprzez uwypuklenie najistotniejszych aspektów tegoż przechowywania. Analizując pierwsze z nich wiele miejsca poświęcił warunkom zabezpieczania zbiorów, tj. budynkom bibliotecznym, konkretnym pomieszczeniom, ochronie księgozbiorów przed zniszczeniem, zwłaszcza zaś profilaktyce i oprawom introligatorskim $^{38}$. W ramach uporządkowania zbiorów, oprócz ich katalogowania, podkreślał wagę dobrego ustawienia, oczywiście działowego ${ }^{39}$, według formatu i sygnatur ${ }^{40}$. Wreszcie wiele pisał o utrzymaniu zaprowadzonego porządku, czyli gotowości księgozbioru do udostępniania ${ }^{41}$. Nauki Lelewela mogły zatem wpłynąć nie tylko na praktykę, ale i na prawodawstwo biblioteczne. Pośrednio wpływ ten widoczny jest w książce Stanisława Dunin-Borkowskiego O obowiązach bibliotekarza z 1829 roku, wydanej z okazji otwarcie Biblioteki Ossolineum we Lwowie. Hrabia Dunin-Borkowski wręcz podkreśla w niej, że: „,...] przy wystawieniu Biblioteki publicznej dwie główne prace zajmować powinny czynności Bibliotekarza. Pierwsza techniczna trudni się wynalezieniem stosownego miejsca na złożenie książek i staranie około ich zachowania. Druga naukowa poświęcona jest uporządkowaniu systematycznemu książek i spisaniu katalogów bibliotecznych"42. W ogóle uważał autor. że : , [...] zamiłowanie porządku należy także do przymiotów Bibliotekarza. Będzie on najtroskliwiej przestrzegał, aby książki czyszczono, przez noc nie zostawiano na stołach, ale każdego wieczora na swoje miejsce składano"43. Jak widać również w piśmiennictwie bibliotekoznawczym ranga przechowywania i konserwacji zbiorów zajmowała w owym czasie wyraźnie pierwsze miejsce pośród innych funkcji bibliotecznych.

Do Powstania Listopadowego nauka, oświata i kultura na ziemiach zaboru rosyjskiego rozwijała się bez szczególnych przeszkód. Sytuacja zmieniła się, jak wiadomo, po jego upadku. Zamknięto wszystkie szkoły wyższe, ucierpiały też

${ }^{37}$ Joachim Lelewel, Bibliograficznych ksiag dwoje.Wilno. Tom 1, 1823. Tom II, 1826. tu: s.264.

${ }^{38}$ Tamże, s. 264-269.

${ }^{39}$ Tamże, s. 272-274.

${ }^{40}$ Tamże, s. 274-281.

${ }^{41}$ Tamże, s. 301

42 Stanisław Dunin-Borkowski, O obowiazkach bibliotekarza. Wyd. Poznań 1929 (Pierwodruk: Lwów 1829), s. 4-5.

${ }^{43}$ Tamże, s. 37. 
biblioteki. $\mathrm{Z}$ wydawanych $\mathrm{w}$ tym okresie przepisów prawa bibliotecznego, np. z 1837 roku w Urzadzeniu wewnętrznym warszawskiej duchownej rzymsko-katolickiej Akademii, do przechowywania zbiorów odnosi się paragraf 134: „Biblioteka Akademii zostaje pod bezpośrednim dozorem bibliotekarza, którego głównym jest obowiązkiem czynnie przykładać się do wszystkiego, czego całość, wzrost i uporządkowanie biblioteki wymaga" (TZ 1997, s. 139). I co ciekawe, osobny przepis mówi wyłącznie o dosłownym zabezpieczeniu zbiorów: „735. Dwa rejestr a biblioteki i dwa klucze być powinny, jeden rejestr i klucz będzie u Rektora, drugi rejestr będzie w bibliotece, a klucz u bibliotekarza". Tuż przed Powstaniem Styczniowym następuje pewna liberalizacja twardej władzy carskiej. W 1862 roku ukazuje się, całkowicie przez Polaków opracowana Ustawa o wychowaniu publicznym w Królestwie Polskim. W niej zwłaszcza art. 370 zasługuje na szczególną uwagę, ze względu na jasne określenie znaczenia przechowywania i konserwacji zbiorów, choć nie tylko: „Kommissya Rządowa Wyznań i Oświecenia Publicznego, na wniosek Dyrektora Honorowego Bibliotek oznaczy szczegóły urządzenia i utrzymania Biblioteki Głównej, sposób udzielania z niej książek, pomnażania i konserwacji jej zbiorów" (TZ 1997, s. 152). Jeszcze ciekawsze pod tym względem, są akty wykonawcze do cytowanej ustawy z 1862 roku zebrane w formie Przepisów Komisji Rzadowej Wyznań Religijnych i Oświecenia Publicznego z dnia 1 (13) lipca 1864 r., a więc z czasów trwania Powstania Styczniowego: „W wykonaniu art. 370 ustawy o wychowaniu w Królestwie Polskim, Komissya Rządowa Wyznań Religijnych i Oświecenia Publicznego, na wniosek zastępcy [to złowrogie echo toczącego się Powstania] Dyrektora Honorowego Bibliotek, po zasięgnięciu zdania Rady Wychowania, następne przepisy, tyczące się urządzenia, utrzymania i pomnożenia Biblioteki Głównej, stanowi i do ich zastosowania się komu należy poleca" (TZ 1997, s.154). Pierwszorzędne znaczenie w tych przepisach maja rozwiązania odnoszące się do przechowywania i konserwacji zbiorów, zwłaszcza do ich zabezpieczenia, ustawienia i konserwacji. Pierwsze dwa $\mathrm{z}$ wymienionych zagadnień przechowywania zbiorów, są mocno widoczne w przepisach: „Podziału biblioteki Glównej [...]. 2. Dział ogólny przy porządkowaniu i katalogowaniu dzieł rozdzielony być winien na dwa następujące działy: a) Dzieła pisane $\mathrm{w}$ języku polskim lub w języku łacińskim przez autorów Polaków, jako też dzieła historyczne w obcych językach drukowane, traktujące o Polsce. Ten oddział nazywać się będzie: Działem Polskim (Polonica), b) Dzieła drukowane $w$ językach rossyjskim i innych sławiańskich. Ten dział biblioteki oznaczony zostanie nazwą Działu Słowiańskiego (Slavica). c) Dzieła wydawane we wszystkich innych językach, tak starożytnych jak i nowożytnych, stanowić mają: dział obcych języków, d) Rękopisma, inkunabuły, rzadkości bibliograficzne, karty jeograficzne wraz ze zbiorem rycin i kosztownych dzieł illustrowanych. e) gabinet numizmatyczny wraz ze zbiorem archeologicznym, obejmującym dyplomata, pomniki sfragistyczne, graficzne" (TZ 1997, s. 154). Ciekawe, czy nie to ustawienie uratowało polskie zbiory, bowiem po upadku Powstania Styczniowego z Biblioteki Publicznej przy Uniwersytecie Warszawskim zabrano wszystkie publikacje obcojęzyczne. Przepisy w sprawie zabezpieczania i konserwacji zbiorów stanowiły bardzo szczegółowo, zwłaszcza w rozdziale Zarzad i attrybucje osób, 
do składu Biblioteki Głównej należacych, gdzie zapisano, że: „3. Zwierzchnie zawiadywanie Biblioteką należą do Dyrektora Honorowego, któremu w pomoc dodaje się Rada, złożona z bibliotekarza, Podbibliotekarza i jednego z Kustoszów, przez Dyrektora Głównego wyznaczonego. 4. Przedmiotem narad na posiedzeniach Rady, zwoływać się mających w razie potrzeby ma być: a) projektowanie rocznego rozkładu summ, na kupno dzieł, ich oprawę, katalogowanie: e) przyjmowanie introligatorów i oznaczanie rodzaju opraw; [...]. 7. Bibliotekarz jest bezpośrednim zwierzchnikiem wszystkich osób do pracowania w Bibliotece przeznaczonych i jest odpowiedzialny za całość Biblioteki”. (TZ 1997, s. 155). I jeszcze tak charakterystyczny dla przechowywania zbiorów przepis o nadawaniu znaków własności z rozdziału Katalogowanie i stemplowanie dzieł, pomnażanie Biblioteki zawarty w paragrafie 18: „Wszystkie dzieła, do Biblioteki Głównej należące, mają być opatrzone stemplem, noszącym napis: «Biblioteka Główna w Warszawie Nr...». (TZ 1997, s. 156). Warto dodać, że początkowo - jak opisuje to Kazimiera Maleczyńska w swoim znakomitym dziele Ksiązki i biblioteki w Polsce okresu zaborów - Szkoła Główna i Biblioteka Główna, jako koncepcja niepopularnego, znienawidzonego nawet, Aleksandra Wielopolskiego nie cieszyła się uznaniem społeczeństwa i napotykano poważne trudności w znalezieniu dla nich kadry. W końcu jednak sprowadzono z zaboru austriackiego, młodego, dobrze zapowiadającego się uczonego jakim był Karol Estriecher. Ostatecznie władze biblioteczne ukonstytuowały się w osobach: zastępca dyrektora honorowego bibliotek w Królestwie, były pijar ks. Adam Jakubowski (stanowisko dyrektora honorowego bibliotek nie zostało obsadzone), bibliotekarz Józef Przyborowski i podbibliotekarz Karol Estreicher. Nominacja Estreichera (17 II 1863) zbiegła się niemal z wybuchem Powstania Styczniowego. K.Estreicher był przeciw powstaniu, nie miał nic wspólnego nawet $\mathrm{z}$ działalnością cywilną na jego rzecz i w okresie najbardziej zawziętych walk prowadził z natężeniem gigantyczną akcję katalogowania ksiąg, być może z myślą o udostępnieniu ich w niepodległym kraju. Praca w Bibliotece Głównej (do 1867) miała dla niego olbrzymie znaczenie. Tutaj zetknął się po raz pierwszy z problemami wielkiej biblioteki naukowej, tutaj okrzepła ostatecznie jego koncepcja «Bibliografii polskiej»" ${ }^{44}$. Nawiasem mówiąć, problemom wielkiej biblioteki naukowej poświęcił swoją pracę Włodzimierz Górski wydając w 1862 roku w Warszawie Krótki kurs zasad bibliotekoznawstwa. Uważał on, że bibliotekoznawstwo: , [...] zawierając w sobie uporządkowane przepisy gromadzenia ksiąg i w ogólności postępowania z nimi, dzieli się na dwie główne części: w pierwszej traktuje o zakładaniu i urządzaniu bibliotek, w drugiej wykłada teorię zarządu biblioteką" ${ }^{45}$. Dalej pisze, iż trzy główne przedmioty stanowią treść tej pierwszej części bibliotekoznawstwa, przy czym dwie z nich, tj. pierwsza i trzecia, dotyczą szeroko rozumianego przechowywania i konserwacji zbiorów: „1. Obiór miejscowości na bibliotekę i wewnętrzne urządzenie całego budynku; 2. Gromadzenie ksiąg, źródła i środki ku temu posługujące; 3. Porządkowanie i katalogowanie dzieł uporządkowanych. Ta ostatnia czynność nadaje dopiero

\footnotetext{
${ }^{44}$ Maleczyńska, Książki i biblioteki, s.77-78.

${ }^{45}$ W. Górski, Krótki kurs zasad bibliotekoznawstwa. Warszawa 1862, s. 5.
} 
pewnemu zbiorowi właściwą cechę biblioteki" ${ }^{46}$. Porządkowanie uznał Górski za najważniejszą czynność bibliotekarską (s. 23) w szczególności zaś opisanie dzieł pojedynczych, systematyczne ustawienie i wreszcie sporządzenie katalogów (s. 25-63). Najwięcej miejsca poświęcił ustawieniu działowemu książek rozbudowując schematy poszczególnych działów nauki, ale zarazem zwracając uwagę na to, że: „,...] książki na półkach bynajmniej ścieśniać nie należy, lecz przeciwnie na każdej półce pozostawić zawsze nieco wolnego miejsca, tak dla swobodniejszego przeciągu powietrza, jak również dla zachowania miejsca na dzieła" ${ }^{47}$. Przy okazji przypomnijmy, że, numerus currens $\mathrm{w}$ ustawieniu zbiorów wprowadził w Polsce Fryderyk Papee. Najpierw od 1893 roku w Bibliotece Uniwersyteckiej we Lwowie, a od 1903 roku w Bibliotece Jagiellońskiej ${ }^{48}$.

Represje po upadku Powstania Styczniowego przebiegały wolniej i bardziej systematycznie niż po upadku Powstania Listopadowego. Szkoła Główna istniała tym samym do 1869 roku, choć wydano kilka aktów prawnych wyraźnie retorsyjnych i sprzeciwiających się ideowym założeniom ustawy o wychowaniu publicznym w Królestwie Polskim. (TZ 1997, s. 40). Niemniej tworzono później w Warszawie szkoły gimnazjalne i progimnazjalne wyposażając je w przepisy o bibliotekach. Przepisy te są niemalże ,śladowe" i w niczym nie przypominają tych, które wydano w roku 1819 w tym samym Królestwie Polskim dla szkół wojewódzkich i wydziałowych. (TZ 1997, s. 41). W zakresie nas interesującym dotyczą jedynie zagadnienia „komu powierzano" biblioteki. Oto fragment Najwyżej zatwierdzonej $w$ dniu 5(17) stycznia 1866 r. ustawy gimnazyów i progimnazyów męzkich w Królestwie dla ludności Polskiej: „Art.44. Biblioteka ma być powierzona bibliotekarzowi, którego wybiera Rada pedagogiczna na lat dwa z grona Nauczycieli" (TZ 1997, s. 160). Z czasem postawienie sprawy politycznej odpowiedzialności za bibliotekę dowodzi przemyślnej kazuistyki prawnej zaborcy umożliwiającej mu, przez organy lokalnej administracji, po prostu działania likwidatorskie z pobudek właśnie politycznych. Mówi o tym fragment Najwyższego rozkazu, objawionego przez Ministra Spraw Wewnętrznych z dnia 5 stycznia 1884 r. o środkach tymczasowych dotyczacych otwierania $i$ utrzymywania bibliotek publicznych i czytelni: „Art. II. Zwierzchnicy, którym nadane jest prawo wydawać pozwolenie na otwarcie biblioteki i czytelni, w razie zachodzącej wątpliwości, co do tego, czy osoba upoważniona do kierowania temi zakładami i wszyscy w ogóle służący przy takowym zasługują na zaufanie pod wzglądem politycznym, obowiązani są własną władzą usuwać takie osoby z biblioteki i czytelni. Art. III. Ministrowi Spraw Wewnętrznych służy prawo: a) wskazywać miejscowym zwierzchnościom te dzieła, które nie powinny znajdować się w obiegu w bibliotekach i czytelniach publicznych, b) zamykać wszelkiego rodzaju biblioteki i czytelnie publiczne zawsze, ilekroć uznają to za niezbędne" (TZ 1997, s.166). Powyższe przepisy stanowią obraz retorsyjnych działań zaborcy po upadku Powstania Styczniowego. Te działania potwierdza jeszcze m.in. późniejsza Uchwata Komitetu Ministrów z dnia 28 czerwca 1902 r. o nadaniu Generat-

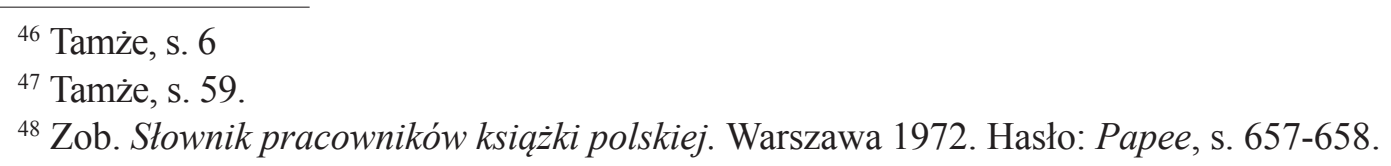


Gubernatorowi Warszawskiemu prawa zamykania wszelkiego rodzaju bibliotek i czytelni publicznych w guberniach Królestwa Polskiego.

Rewolucja 1905 roku oraz przegrana wojna z Japonią (1904) chwilowo osłabiły potęgę autokratycznego państwa. Wtedy też ustalono w Rosji pewne zalążki rządów konstytucyjnych, a nawet pojawił się Ukaz najwyższy z dnia 4 marca 1907 r. o przepisach tymczasowych o towarzystwach i zwiazkach, zezwalający towarzystwom m.in. na „urządzanie bibliotek”. (TZ 1997, s. 43). Powołano więc wiele towarzystw. Interesujący jest szczególnie jeden z paragrafów Towarzystwa Przyjaciół Nauk w Wilnie z 1907 roku, w którym mianem konserwatora określa się bibliotekarza (!): „Art. 17. Walne Zgromadzenie Towarzystwa wybiera siedmiu członków Zarządu, którzy wybierają z pośród siebie: [...], 5. Bibliotekarza (konserwatora). Uwaga: W razie potrzeby na stanowisko Bibliotekarza (konserwatora) Towarzystwo powołać może Zarząd osobny z ogółu członków Towarzystwa lub nawet poza Towarzystwem stojące" (TZ 1997, s. 180). Natomiast w Ustawie Towarzystwa Biblioteki Publicznej i Czytelni imienia Adama Mickiewicza w Kaliszu z 1908 roku za środek prowadzący do osiągnięcia celu Towarzystwa uznano, co zrozumiałe: ,[...] utrzymywanie w odpowiednim lokalu księgozbioru i wypożyczalni książek i czasopism. (TZ 1997, s. 181). Liberalizacja polityki wewnętrznej w zaborze rosyjskim po 1905 roku zrobiła swoje. Z punktu widzenia prawnego carskie restrykcje nie odniosły skutku. Samoorganizujące się społeczeństwo polskie, zaczęło tworzyć prywatne szkolnictwo oraz różnego rodzaju społeczne organizacje naukowe i oświatowe, a w ich liczbie wcale niemałą rolę odgrywały inicjatywy organizowania powszechnie dostępnych bibliotek i czytelni. (TZ 1997, s. 46).

W zaborze austriackim na części terytorium: Królestwa Galicji i Lodomerii (1815-1918) nastąpiło, trwające do 1867 roku, gwałtowne załamanie się szkolnictwa i kultury polskiej. Dopiero okres autonomii - całkowicie i diametralnie odmienił polityczną sytuację ludności polskiej. W 1867 roku ustanowiono Radę Szkolną Krajową funkcjonującą nieprzerwanie do zakończenia I wojny światowej. A w 1869 roku wydana zostaje odpowiednia ustawa „ustanawiająca zasady nauczania w szkołach ludowych", która określiła rolę biblioteki nauczycielskiej jako jednego ze środków pedagogicznego i naukowego kształcenia. (TZ 1997, s.48-49). Najbardziej jednak nas tu obchodzące jest Rozporzadzenie c.k. Rady Szkolnej Krajowej z dnia 24 lutego 1874 r. w sprawie instrukcji tyczacej się zakładania i utrzymywania księgozbiorków przy szkołach ludowych. Przepisy tej instrukcji szczególny nacisk kładły właśnie na szeroko pojęte przechowywanie i konserwację zbiorów: ,[...] Art. 3. Zarządcą księgozbiorku jest kierownik szkoły. Jego obowiązkiem jest: a) przechowywać książki i utrzymywać dokładny ich spis; [...]. Art. 6. Każde do księgozbiorku szkolnego dzieło ma być, czy to pieczęcią, czy stosownym napisem jako własność szkoły oznaczone, tudzież opatrzone bieżącym numerem, pod którym należy je do spisu książek zaciągnąć, wypisując cały tytuł, sposób nabycia i ceną, jeśli jest kupione. Wszystkie książki mają być mocne i trwale oprawione i o ile możności w zamykającej się na klucz szafce przechowywane: [...]. Art. 10. Obowiązkiem zarządcy księgozbiorku jest czuwać nad tem, ażeby żadna z książek nie zginęła, i ażeby wypożyczone we właściwym 
terminie zwracano. W razie zagubienia lub uszkodzenia książki ma zarządca wezwać winnego do zwrotu wartości książki i uwiadomić o tem Radę szkolną miejscową" (TZ 1997, s. 198).

Głównie o dozorze nad poszczególnymi bibliotekami mówią odnośne przepisy wydawane w zaborze pruskim, a także Wielkim Księstwie Poznańskim (1815-1918). W ogóle prawo biblioteczne stanowione na tym terytorium jest najuboższe $\mathrm{w}$ porównaniu $\mathrm{z}$ innymi zaborami. Oto przepisy stanowionej $\mathrm{w}$ będącej jeszcze w zaborze pruskim Warszawie (tj. do czasów Ks. Warszawskiego) Ustawy Towarzystwa Warszawskiego Przyjaciół Nauk. uchwalone przez Towarzystwo w $1800 \mathrm{r}$ : ,,[...] Art. 31. Bibliotekarza powinnością jest zarządzać biblioteką Towarzystwa” (TZ 1997, s. 213). A także równie ważnego, bo będącego zalążkiem przyszłego Uniwersytetu Warszawskiego Urzadzenie Liceum Warszawskiego. Dan w Berlinie dnia 23 czerwca 1804 roku: ,[...] Art. 72. Szkoła opatrzona będzie w bibliotekę, zawierającą książki do nauki tak dla nauczycielów, iak i uczniów. Dyrektor sam lub profesor Kamery zalecony przez niego, mieć będzie dozór nad biblioteką" (TZ 1997. s. 214). Dla spraw bibliotecznych związanych z przechowywaniem i konserwacją zbiorów ciekawe są nadto Ustawy Towarzystwa Literacko Stowiańskiego we Wrocławiu, zatwierdzone przez władze wyższe 15 lutego 1859 r. W Tytule IV. Wewnętrzne Urządzenie Towarzystwa, art. 7 mówi, że: „Bibliotekarz ma książki pod dozorem. Obowiązkiem jego jest książki utrzymywać, spis dzieł urządzić, lub jeżeli jest wypełniać. Rozpożycza książki i regularnie je odbiera. Skupuje z polecenia Towarzystwa i każe oprawiać dzieła oraz odbiera darowane książki” (TZ 1997, s. 219). Wskazując na małą liczbę aktów prawa bibliotecznego powstałych na terenie zaboru pruskiego, trzeba tu przytoczyć zastrzeżenie Zarzębskiego, że brak pełniejszej liczby przepisów tegoż prawa tłumaczyć należy faktem, iż większość decyzji wobec ludności polskiej podejmowano w trybie postępowania administracyjnego - na podstawie ogólnie obowiązującego prawa pruskiego, a później II Rzeszy. (TZ 1997, s. 56). Również w czasie I wojny światowej na części terytorium kraju: Jenerał Gubernatorstwie Warszawskim i Lubelskim wydano ich niewiele. Nowe Statuty Uniwersytetu i Politechniki Warszawskiej oddają biblioteki pod zarząd ich kierowników, natomiast w Ustawie Związku Bibliotekarzy Polskich z dnia 2 lipca $1917 \mathrm{r}$. w punkcie „„” jest zapisane, że ZBP ma na cele m.in.: ,czuwanie nad prawidłowym rozwojem polskich bibliotek, czytelń i archiwów". (TZ 1997, s. 223). Prawidłowym, czyli domyślnie, z odpowiednią polityką zabezpieczającą zbiory. Zatem nowy okupant ziem Królestwa Polskiego usposobiony był raczej przyjaźnie do ludności polskiej, a to wskutek współdziałania (po stronie państw centralnych) polskich organizacji wojskowych pod dowództwem Józefa Piłsudskiego. (TZ 1997, s. 56).

Reasumując, trzeba podkreślić, że w ujęciu historycznym prawo biblioteczne w Polsce pozostanie na zawsze dowodem troski o należyte przechowywanie i konserwację zbiorów. Chlubną tradycję w tej mierze można liczyć już od aktów prawnych Komisji Edukacji Narodowej, które miały niewątpliwy wpływ na prawodawstwo biblioteczne w Polsce przez cały okres zaborów. Zasadniczymi pozytywami tego ustawodawstwa były prawa zabezpieczające księgozbiory przez stanowienie jednoznacznych personalnych kurateli, następnie stwarzanie warun- 
ków dobrego przechowywania zbiorów przez dobór odpowiednich lokali, a także ochrony księgozbiorów przed zniszczeniem połączone z działaniami profilaktyczno-konserwatorskimi. Prawo to dbało o uporządkowanie i skatalogowanie zbiorów i stałą ich gotowość do udostępniania, oczywiście, pod odpowiednimi warunkami zapobiegawczymi chroniącymi książki przed uszkodzeniami czy zaginięciami. Zatem oceniając rozwój i wprowadzane zmiany akcentów w problematyce przechowywania i konserwacji zbiorów, musimy podkreślić wzajemną zależność pomiędzy kodyfikacją prawną $\mathrm{w}$ tym zakresie a zagadnieniami opieki nad zbiorami, rozważanymi w ówczesnym polskim piśmiennictwie bibliotekoznawczym. Omawiają one wspomniane kluczowe problemy przechowywania i konserwacji zbiorów właściwie już skodyfikowane, usystematyzowane, a co najważniejsze ustalone przede wszystkim przez Joachima Lelewela w Bibliograficznych ksiag $d w o j e$. Przetrwały one zresztą do czasów nam współczesnych ${ }^{49}$.

Akty prawa bibliotecznego do 1918 roku w zakresie interesujących nas zagadnień, reprezentowały konsekwentne postępowanie biblioteczne samoorganizującego się światłego społeczeństwa polskiego, polegające na kierowaniu spraw związanych z przechowywaniem i konserwacją zbiorów w taki sposób, aby za wszelką cenę zachować te zbiory dla potomności. Ich ochrona przed zniszczeniem była bardzo ważnym, a może najważniejszym problemem prawodawstwa i piśmiennictwa bibliotecznego $\mathrm{w}$ omawianych okresach. Lecz swoje apogeum ważności odniosło w zupełnie innym - choć podobnym pod pewnymi względami - czasie. Specjalnie bowiem i wyjątkowo, wagę ochrony zbiorów uwypuklono i to w tytule pierwszego w Polsce Dekretu o bibliotekach z 1946 roku Jego pełna nazwa brzmi przecież: Dekret z dnia 17 kwietnia 1946 roku o bibliotekach i opiece nad zbiorami bibliotecznymi. (TZ 1991, s. 110). Nigdy wcześniej, ani nigdy później funkcja przechowywania i konserwacji zbiorów nie osiągnęła tak wysokiej rangi, aby wspominać o niej od razu już w nazwie najwyższego bibliotecznego aktu prawa. Ale czy po straszliwych zniszczeniach księgozbiorów polskich w czasie II wojny światowej można się temu dziwić?

${ }^{49}$ Por. hasła: Przechowywanie zbiorów oraz konserwacja zbiorów, w: Encyklopedia wspótczesnego bibliotekarstwa polskiego, Wrocław 1976, s. 254, 177. 